\title{
Sovereign British Bases on Cyprus and Their Impacts on the Maritime Delimitation in the Eastern Mediterranean
}

\section{Gökhan AK•}

\begin{abstract}
Cyprus puzzle" could not be made out without putting all the related parts together. Thus in the basis of British and American strategies towards the Eastern Mediterranean and Cyprus Island, national interests, which encircle their global hegemony challenges play the most noteworthy role. Besides, there are remarkable issues happening around the island apart from the main dispute between Turkish and Greek Cypriots of the island, known as "Cyprus Question". New natural gas berths discovered under the seabed drew the eyes of the regional states as well as global powers such as the Unites States of America, the United Kingdom (UK), the Russian Federation, and European Union towards the waters around the island. Natural energy resources are essential and infact vital for every society and state on earth. Apart from this fact, regional states of the EasternMed attempted quickly for seeking ways to delimitate maritime areas of the Eastern-Med in line with the arrangements of the law of the sea. However, there is a very-far, but in fact a so-close hegemon in the Eastern-Med region as if a next-door neighbour. This is the UK, which could easily claim rights on the maritime jurisdiction areas around the island since the UK has two sovereign bases located in the southern part of Cyprus. In this respect, this study has been designed to focus on the Sovereign British Bases on Cyprus, their global connections, and their impacts on the Eastern Mediterranean maritime jurisdiction areas conflict, that is believed to be one of the most prominent, but (un)intentionally overshadowed piece of the Cyprus puzzle.
\end{abstract}

Keywords: $\quad$ Eastern Mediterranean, Cyprus, Maritime Delimitations, Sovereign British Bases, Law of the Sea, Global Interests and Challenges

•Ph.D. in Political Science, Nişantaş1 University, İstanbul, gak2081@ yahoo.co.uk 


\section{Introduction}

Developing technologies and increasing global enegy needs boosted for exploring and discovering new hydrocarbon resources in the Eastern Mediterranean. Latest discoveries in this field of energy sector mainly point out that the region will possibly become a significant natural gas hub in the $21^{\text {st }}$ century ahead. In the United States (US) Geological Survey Reports, a probable amount of 122 trillion cubic feet (Tcf) natural gas exists in the Levant Basin, south of the island and off-shore Israel coast. ${ }^{1}$ This sort of huge amount of hydrocarbon reserves will naturally mean as energy resources for the whole world, but mainly for the Europe.

However, this richness, which normally indicated a future-probable prosperity in the EasternMed, also became the messenger of newly-arising disputes, the size and intensity of which increase sharply from time to time. This situation verifies the verdict of the statement "no rose without its thorns" since new sources and richness of energy may easily enable the collision of new interests, which delves into being a new dispute in the region. New conflicts also affect negatively the old disputes in the region including those related to the Aegean Sea -mainly- between Greece and Turkey. Therefore, it is possible to note that conflicts due to the discoveries of the new resources not only deepen the old disputes, but also situated themselves being unsolved as well with regard to the old disputes. ${ }^{2}$ For the old disputes in the region, it could be recounted as Cyprus Question, Greco-Turkish Issues, Israel-Arap States as well as Israel-Palestine Issues. For the new ones in this context, the civil war in Syria, domestic political turmoils and disorder in Egypt and Libya could be mentioned primarily.

However, in the last decade, potential off-shore natural gas fields have been discovered in the Eastern Mediterranean basin. Hydrocarbon sources discovered under the seabed of Eastern Mediterranean is a newly-born maritime dispute of international law, which set out just into the middle of the regional conflicts mentioned above. Regarding democratic development, regimes, historical antagonisms and enmities in the region, it could easily be claimed that the existence of this recently-discovered natural sources points out a slight appearence of possiblity in the contribution to the solution of the old and current conflicts among the regional states. The reason for that could be that this natural sources existence will likely to help increase the unbalance between the economical interests and political conflicts of the regional states. This unbalance will thus tumble down all the inter-relations as well as mutual ones among nations of the region as well.

International mass media showed an awesome interest in the rich natural sources discovered around Cyprus under the seabed of the Eastern-Med. However, this great interest misses to perceive the role of an out-of-area actor while the regional states ambitiously delve into national initiatives in sharing and limitating strategies regarding the sea areas in the region. This out-of-area actor is the UK - a hegemon, which never cut off her interest and strategy with the region since 1878. Thus the significant and indispensible relations of the UK with the Eastern Mediterranean will mostly overlooked by the regional states.

The UK currently owns $3 \%$ sovereignty of Cyprus territory. The reason for that stems from history. The British national interests and strategies towards the Middle East and Far East in general, but the Eastern-Med and Cyprus island in private order lasted more than a century. These British national interests and strategies had always been the main nourishment for the UK's global hegemonic challenges and contentions.

In this context, the main purpose and target of this study is the Sovereign Base Areas of the UK on Cyprus, which were mostly overlooked and underestimated due to the reasons known and/or unknown in the Cyprus Question as well as newly-disputed issue of hydrocarbon richness around the island. This study in this sense has been designed to focus on the Sovereign British Bases on Cyprus, 
their global connections, and their impacts on the newly-arisen regional conflict regarding maritime delimitations in the Eastern-Med.

\section{Relations between International Law of the Sea and Seabed Hydrocarbon Sources}

Hydrocarbon resources discovered around Cyprus island occured to be harbinger of a new dispute at sea in the Eastern-Med region. However, this is not the herald of something good. It is infact the dispute over how to share vast sea areas and thus limit maritime jurisdiction areas by the littoral states of the region. Since this conflict has been originated from the principles of international law of the sea, it would firstly be appropriate to go through some basic rules of international law related to the delimitation of maritime jurisdiction areas. The issue will be able to be recognized more clearly and effectively in this way.

The states may have territories, sea areas and airspace. ${ }^{3}$ However, there are also maritime areas around coastal states, which submit some sovereign maritime rights to those relevant coastal states. Apart from territorial, insular, inland waters, fishery zones, there is a notional combined approach between the continental shelf (CS) and exclusive economic zone (EEZ). The CS is an underwater landmass, which extends from a continent, resulting in an area of relatively shallow water known as a shelf sea. A littoral state has "ab initio" and "ipso facto" rights on the CS under the 1982 United Nations Convention on the Law of the Sea (UNCLOS). ${ }^{6}$

In other words, a littoral state has certain rights related to the CS from the beginning of being in force the rules of the CS without a need for declaration. The meaning of this for the Turkish Republic of Northern Cyprus (TRNC) and Turkey is in essence that both states have the CS in the Eastern Mediterranean.

The legal definition of a CS differs significantly from the geological definition. UNCLOS states that the shelf extends to the limit of the continental margin, but no less than 200 nautical miles ${ }^{7}$ $(\mathrm{nm})$ from the baseline. An EEZ is a sea zone prescribed by the UNCLOS over which a littoral state has special rights regarding the exploration and use of marine resources, including energy production from water and wind. It stretches from the baseline accepted out to $200 \mathrm{~nm}$. from its coast. In colloquial usage, the term may include the CS. Thus the main relation between CS and EEZ is that EEZ covers both the richness at the bottom and under the seabed and in the mass of sea water. ${ }^{8}$

In this line, it would be more appropriate to recount EEZ in the Eastern-Med region since our counterparts declared EEZs in this region. And they have a common understanding of concluding numerous bilateral treaties concerning the maritime delimitations in the region.

\section{Latest Developments in the Region Regarding the Delimitation of EEZ}

It could be set out easily that the Eastern Mediterranean region, which attracts today a vast amount of international interest in hydrocarbon transportation, exploration and production, has been one of the world's most strategic regions. It has been the center of many energy and maritime related crisis in the past and current times. Today, as a continuation and result of old disputes in/around the region, ${ }^{9}$ maritime delimitation of boundaries has arisen as a major dispute for the states in the Eastern Mediterranean.

The waters around Cyprus were so-boiled up by the off-shore hydrocarbon richness adding new harsh flames to the commonly hot international politics of the region. Greek Cypriots noticed this richness around the island during 1990s open-eyedly. After 2000, the local media in the south of 
the island commenced to cover this issue more often. The Cyprus Question has long been an obstacle for the region's stability and security, and the divided position of the island is an inevitable fact of the region today. Therefore, since there is not a common federation government representing both sides of the island, it seems as if Greek Cypriots had felt themselves as the sole owner of the richness under the seabed. It is well to remember that the rich natural gas areas are discovered in the south of the island at sea -for the time being.

This dispute was a political problem as well as an economic one. Its impacts on the solution of the dispute on the island between two sides were somewhat clear when looked at the talks between the leaders of both sides. But it became clear in a short period of time that was not the case. The approach of Greek Cypriots to this richness was unilateral and not partner-liked. Normally it is anticipated that this richness should be under common ownership of the both sides. However, the meaning of joint values or a common future of the island folks had been forgotten on Cyprus for a long time ago. So this situation was not out of common for it is proved by the unilateral initiatives of Greek Cypriots, who concluded agreements on the maritime delimitations of EEZ with Egypt, ${ }^{10}$ Lebanon $^{11}$ and Israel ${ }^{12}$ sequentially and bilaterally. ${ }^{13}$

TRNC and Turkey has not declared any EEZ in the region yet. This does not mean they both will follow this politics forever. On the other hand, both TRNC and Turkey objected to the unilateral initiatives of Greek Cypriots regarding delimitation maritime areas around the island from the outset. Both Turkish states firstly and consistently called attention of the international society to the fact that any sort of delimitation of the sea areas in the region should be handled and concluded in line with the principles of justice and equity of the international maritime law. ${ }^{14}$ It should be taken into account that the Eastern Mediterranean is a semi-enclosed sea consisting of multiple littoral states such as Turkey, TRNC, Syria, Lebanon, Israel, Egypt, Libya, Greece and the Greek Cypriot Administration of Southern Cyprus (GCASC). Thus achieving a fair maritime delimitation in this region crowded with many coastal states is a complex issue. However, it is unlikely to argue that this matter should be realized on the basis of international law and should not infringe upon third parties' rights. ${ }^{15}$

Although many disputed issues in the world remain to be unsolved, it is a crystal-clear fact that TRNC is a sovereign state located in the northern part of the island, and Greek Cypriots respresent only their sovereign part of the island in the south, but not the whole island. Therefore TRNC and Turkey declared that they both would not accept the agreements that Greek Cypriots has concluded unilaterally with some other littoral states of the region. Turkey also declared in the UN by issuing a memorandum note ${ }^{16}$ to the Secretary General (SecGen) in March 2004 quoating that Turkey does not accept the EEZ agreement between Egypt and Greek Cypriots, and Turkey has her own EEZ rights in the western part of the latitude $32^{\circ} 16^{\prime} 18^{\prime}$ ' $\mathrm{E}$. In this context, it is surely possible to note that Cyprus issue was widened from lands to the waters around the island.

On the other hand, the attention of the world's famous energy companies is quietly on the waters of the Eastern Mediterranean on every hand. Energy companies normally argue that there are huge oil and gas reserves in the little-explored Mediterranean Sea between Greece, Turkey, Cyprus, Israel, Syria and Lebanon. But, while the GCAC has been pursuing an adventurous policy in the Eastern Mediterranean through concluding maritime delimitation agreements, they sharply increased the tensions by conducting oil/gas exploration and issuing permits to some international energy firms for such activities around the island. A U.S. energy company, Noble Energy, noted that the natural gas discovery in the Eastern Mediterranean Block-12 south of island has estimated gross mean resources of $7 \mathrm{Tcf}$, and Leviathan $17 \mathrm{Tcf}$ of gross natural gas mean resources, representing the largest deep-water natural gas discovery in the world over the past decade. ${ }^{17}$ As a result, it seems that the region is attracting the global energy companies' interests today. ${ }^{18}$

Considering the developments related to the issue of the Eastern-Med, in order to preserve the legal rights of the Turkish Cypriots, Turkey and TRNC had forwarded a tough step between both 
states by signing a limitation of the CS agreement on 21 September 2011. In a few days following this event, a licensed survey ship (R/V Piri Reis) conducted 2V seismic surveys in the CS of TRNC. Some of the areas that R/V Piri Reis conducted surveys were in the southern seas of the island, which overlapped with Greek Cypriots blocks where Greek Cypriots and other oil companies were exploring.

\section{Sovereign British Bases on Cyprus: Features and Global Significant Connections}

British presence on Cyprus is not a coincidence since the UK had been an imperial and hegemonic power of the modern times. Cyprus was placed under British administration on 4 June 1878. The importance of the island for British governments at the end of $19^{\text {th }}$ century was mainly to establish a secure chain across Gibraltar-Malta and Cyprus in the Mediterranean basin. ${ }^{19}$ In the $20^{\text {th }}$ century for the British, this significance evolved into securing the lines of oil to their main homeland - England, and in this sense to control Suez Canal that is one of the most important choke-points in the Mediterranean. In the $21^{\text {st }}$ century, in addition to all these necessities, Cyprus acts as an forwardoperational base of the UK for military operations conducted in the Near East, Middle East and Avrasia in which the UK took part.

Infact there are striking and outstanding points when the Constitution establishing the 1960 Republic of Cyprus is examined in detail. A discreet analysis of this Constitution shows that it mainly considers and protects the interests and rights of the UK presence on the island from the outset. ${ }^{20}$ The agreements that established the 1960 Republic on Cyprus gathered and issued in the 22 Annexes in total. While the first part in the Constitution constitutes the establishment of the Sovereign British Bases on the island, the Constitution itself had found its place solely in Annex-D. This approach emphasises clearly a fact that the sovereign bases are more important for the UK than the Repuclic of Cyprus. In essence the UK ceded her all sovereign rights to the new 1960 Republic of Cyprus in line with the Zurich agreement dated February 19, 1959 except two sovereign base areas and some military facilities on the island. ${ }^{21}$

Treaty concerning the Establishment of the Republic of Cyprus preceded the 1960 Constitution of the Republic as Annex-A, and included the formations of the Sovereign British Base Areas in six appendices. In this way, the UK retained the two Sovereign Base Areas of Akrotiri and Dhekelia. These are the British Overseas Territories administered as Sovereign Base Areas. The British base areas are 99 miles square, and under British sovereignty with their own laws, courts, military and civilian police organization. The bases had been intensely used for military intelligence, electronic listening, U-2 surveillance planes flights and many other military purposes during the Cold-War. ${ }^{22}$ Following the Cold-War, these British bases on the island were easily at hand to deploy military interventions and operations in Iraq and Afghanistan. While the GCASC had been offered a full-membership to the EU, the status of these sovereign British bases were in dispute, but at last it was decided that these base areas would stay as sovereign British territory, but not the EU. ${ }^{23}$

Another remarkable point about these British bases on the island is that they are accepted as single-sovereign states according to the World Factbook 2005 issued by the CIA. ${ }^{24}$ For instance, in the web-page of the CIA, it is stated for "AKROTIRI State" that Chief of State is Queen Elizabeth II since 6 February 1952 and head of government is Administrator Major General Richard Cripwell since January 2013. For "DHEKELIA State", it is stated that Chief of State is Queen Elizabeth II since 6 February 1952 and head of government is Administrator Air Vice Marshall Graham Stacey since 4 November 2010. ${ }^{25}$ The Akrotiri state conducted an amphibious exercise named as "Cyprus Lion" with her dependency state, the UK, on her territory and territorial waters around Cyprus in 2011. The British forces participating into this exercise were larger than the previous ones, including 
an amphibious landing/assault ship carrying 15 choppers and six different types of naval vessels, British Air Forces, Land Forces and Marine assets. This exercise would have been on Sardegna and its territorial waters at first, but as a last minute change, it was diverted into the territorial waters of the Akrotiri state. Thus the phrase "Akrotiri territorial waters" took its place in the political literature for the first time. It is significant for there are not direct references to the territorial waters or EEZs of the sovereign British bases in the 1960 agreements. ${ }^{26}$

However, Intelligence and Research Bureau, Office of Geography of the US Secretary of Defence issued a food-for-thought paper named as "International Boundry Study - Series A: Limits in the Seas", No. 49 on 10 November 1972. In this work-sheet, one of the sub-paragraphs was called "Territorial Sea Boundry / Cyprus-Sovereign Base Area (U.K.)". In this section of the paper, which was not a formal document, but a food-for-thought work, it is emphasized about the Sovereign British Bases on Cyprus:

When Cyprus became independent in 1960, the United Kingdom retained, as sovereign British territory, certain base areas on the island. These non-ceded lands did not pass to the new state. The limits between the base areas and Cyprus were precisely delimited as international boundaries, and provisions were mad efor the demarcation on the lines. In addition, Section 3 of the Treaty Concerning the Establishment of the Republic of Cyprus provided for territorial sea boundaries between the Republic and the U.K. Sovereign Base Area (SBA). These limits also may have a potential influence on continental shelf boundaries although the possibility is not dealt with specifically in the treaty. ${ }^{27}$

In the work-sheet, there are also charts attached including CS till 200 meters depth beginning from the baseline as the British bases accepted $3 \mathrm{~nm}$. territorial waters.

As clearly seen, the states protect their national interests not only on their territories known as "Motherland", but also on their sovereign seas that could be named "Blue Motherland" such as territorial, insular, inland waters, fishery zones, CSs, EEZs. These sea areas stemming from the principles of the international law of the sea are known as maritime jurisdiction areas, which are subject to any sort of delimitation. Therefore, it is a crystal-clear fact that there is no legal obstacle for the Sovereign British Bases to claim easily one of -or more than- these maritime jurisdiction areas extending out to the Eastern-Med waters in front of their sovereign base territories.

\section{The Impacts of Sovereign British Bases on Eastern-Med Maritime Delimitations}

In the Establishment Treaty, the United Kingdom of Great Britain and Northern Ireland, the Kingdom of Greece and the Republic of Turkey are of the one part, and the Republic of Cyprus of the other part. ${ }^{28}$ In the charts annexed to the Establishment Treaty, the limits of Akrotiri and Dhekelia Sovereign Base Areas were declared as clear and detailed as possible and emphasized in detail that the coastal-lines and territorial waters related to the bases would be under the sovereignty of them. Coastal-line of the both sovereign bases has a length of circa $79 \mathrm{~km}$. that makes $10 \%$ in the $782.5 \mathrm{~km}$. coastal-line of the whole island. ${ }^{29}$

Declarations made by the British authorities from time to time concerning the explorations of hydrocarbons in the territorial and contiguous waters of the Sovereign Bases attract the attentions to the coast-lines of the Sovereign Bases, and their place as well as importance in the matter. ${ }^{30}$ This also evokes an issue that has not been considered properly before. That is the question of the "amount" of their sovereignty on the waters in front of their sovereign territories extending miles and miles outwards the south of Cyprus into the Eastern-Med. ${ }^{31}$ 
The related articles of the Treaty concerning the Establishment of the Republic of Cyprus, which was concluded on 16 August 1960, put the Republic of Cyprus under the obligation that a sovereignty claim related to territorial waters in general could not be directed towards the waters in front of the Sovereign British Bases. Thus it would not be wrong to allege that this approach of the aggreement emphasized the delimitation of maritime areas between two sovereign states, which were the Republic of Cyprus and the UK. On the contrary, it is disputable whether the same agreement delimited other maritime areas such as CS or EEZs. ${ }^{32}$ In the agreement, it is not clear that the waters lying ahead of the territorial waters of the Sovereign Bases represent the open seas or any CS sor EEZs. There is no reference to any maritime areas except territorial waters in the related article of the agreement. ${ }^{33}$

However, it would be inappropriate to consider that the UK would stay indifference to the issue of maritime delimitations in the Eastern-Med. For instance, in the Greek media, some news suggesting that the UK could claim share from the hydrocarbon richness because of the position and the rights of her Sovereign Bases on Cyprus in near future. ${ }^{34}$ The GCASC authorities even alleged some suggestions that London considered to claim her sovereign state rights for her Sovereign Bases on Cyprus in order to get her share of the hydrocarbon wealth around the island. ${ }^{35}$ HMS Enterprise, a maritime research vessel of the UK Fleet, conducted the surveys off-shore Akrotiri and Dhekelia Bases on 7-10 February 2005. ${ }^{36}$ So it is for sure possible to note this: Although the UK declares in the media that she is not interested with the hydrocarbons around Cyprus ${ }^{37}$ the final British attitude will become definite by the amount of hydrocarbon richness in the region. ${ }^{38}$

Another interesting point related to the issue is that the UK has no clear objections to the unilateral initiatives of the GCASC, which declared survey parcels at sea and issued licences to relevant energy companies even though these surveys were being conducted in the sea areas that were blocking some parts of the maritime jurisdiction areas of the Sovereign Bases as well. For the time being, there is no open source known, which indicates any UK objection towards the GCASC side. Thus this current unique position of the UK is questionable and brings into mind that her vague attitudes and approaches could be part of a greater strategic plan and play in the region. ${ }^{39}$

\section{Conclusions}

In this research study, as seen in detail that our anticipation for the Eastern Mediterranean became the region surrounded by Turkey, TRNC, Syria, Lebanon, Israel, Palestine, Egypt, GCASC, Libya and Greece. Sovereign British Bases, Akrotiri and Dhekelia, on Cyprus own their maritime areas such as territorial waters, which were protected from the claims of the Republic of Cyprus under the provisions of section 3 of the 1960 Establishment Treaty. Thus the positions and impacts of these bases on the recent maritime delimitations in the Eastern-Med necessitate further studies and considerations. ${ }^{40}$

Akrotiri and Dhekelia are the British Overseas Territories administered as Sovereign Base Areas. They are directly dependent to the mainland UK. Their legal status and British sovereignty over them are not disputable for sure. These bases are located in a very strategic and jeopolitic geography, which directly holds the control of the areas and choke points streching until Far East. Therefore it could not be a wise manner to consider that the UK might give up or abandon these strategic territories.

On the other hand, from past to present, the availability of Sovereign British Bases for not only British forces, but also US and Canadian forces in numerous purposes, is an additional factor eliminating any possibility for the UK to give up the essential military assets and capabilities in these Cyprus bases. ${ }^{41}$ 


\section{Gökhan AK}

In sum, it is absolutely clear that the national and global interests of the UK in this matter prove to be irresistable as we tried to put forth for further considerations. Hydrocarbons richness, which could be reached and exploited effectively, would likely to be in close interaction with the Cyprus Question as well as national interests of the UK in the region in the near future. Thus, for the time being, it is at least probable for the UK politics to consider claiming -or not- any British CS or EEZ on the southern Cyprus waters in order to contribute to the solution of Cyprus Question in any way concerning hydrocarbon richness.

\section{ANNEXES:}

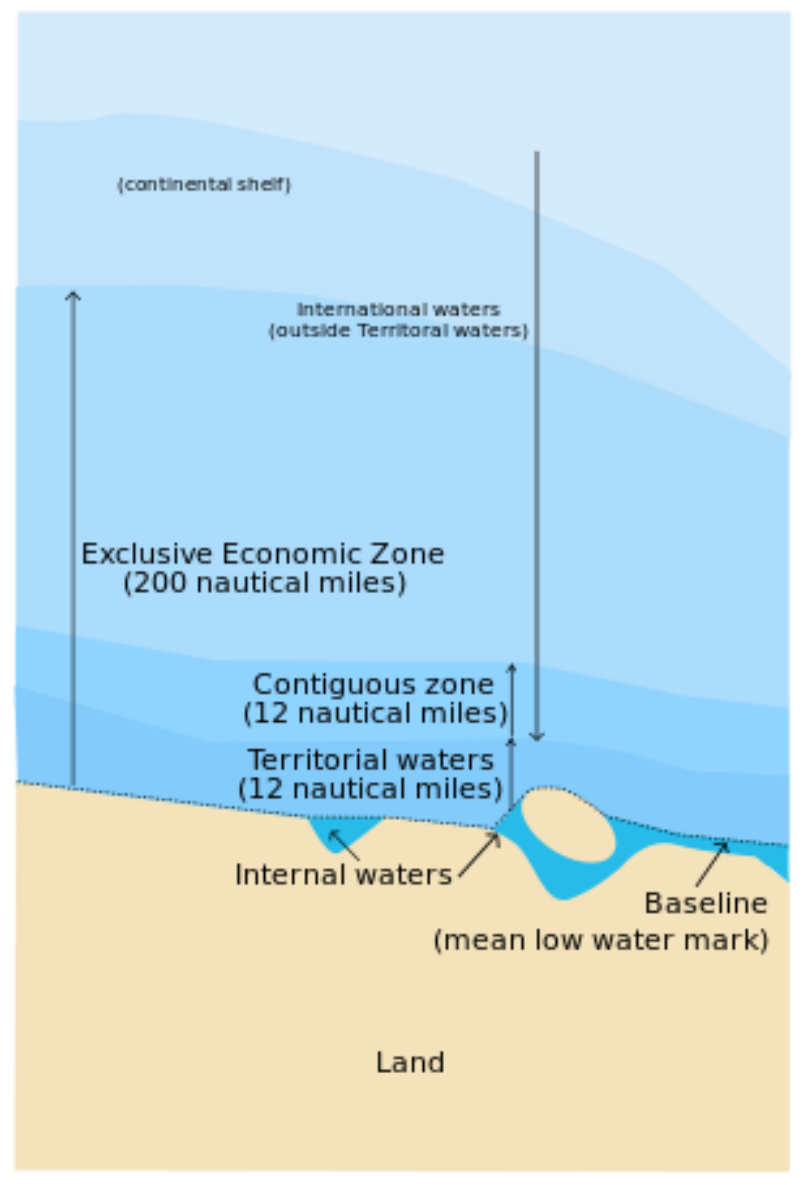

Annex - 1: Sea Areas in International Rights ${ }^{42}$ 


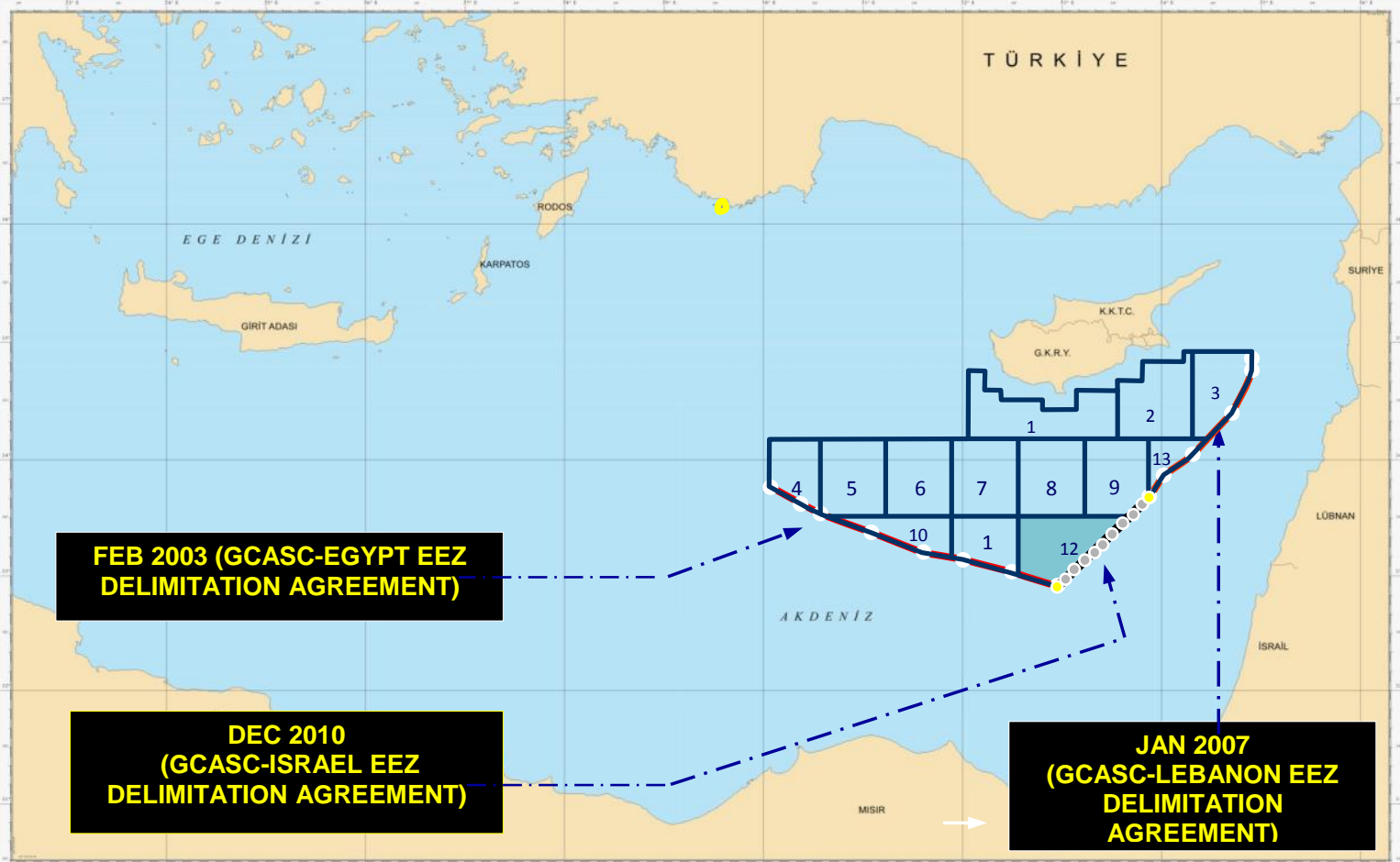

Annex - 2: EEZ Agreements Concluded by the GCASC in the Eastern-Med

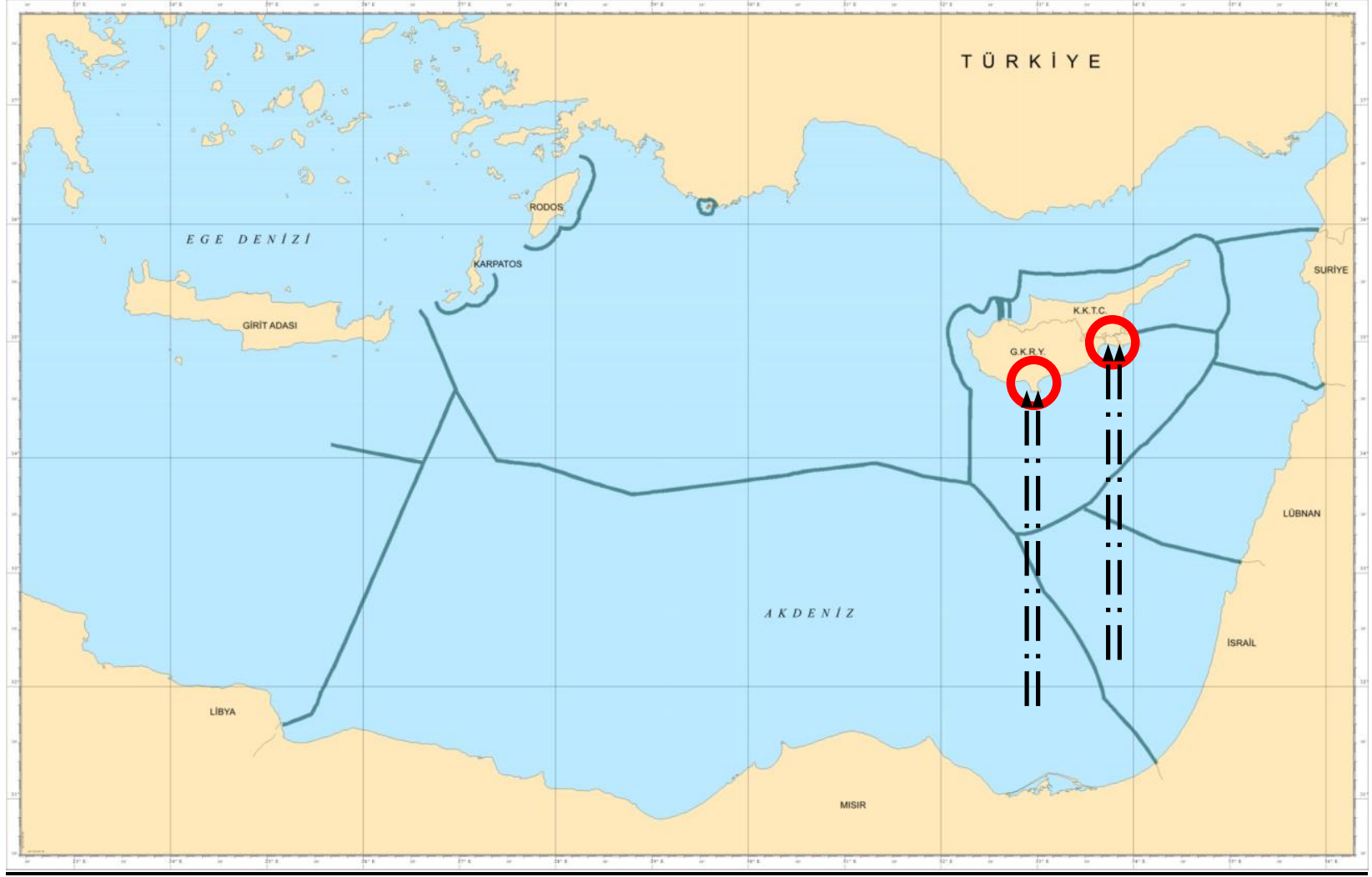

Annex - 3: Possible Maritime Jurisdiction Areas of Sovereign British Bases in the Eastern-Med 


\section{Notes}

1 See "Assessment of Undiscovered Oil and Gas Resources of the Levant Basin Province, Eastern Mediterranean", USGS (The US Geological Survey) Report, accessed December 12, 2014, http://pubs.usgs.gov/fs/ 2010/3014/pdf/FS10-3014.pdf. However, according to some other reports, the amount of the hydrocarbon wealth here in this region is not so much as it is expected; “...at present, the RoC's entire estimated gas reserves of $198 \mathrm{bcm}$ would only supply less than six months of the annual gas consumption of the European Union (EU), which in 2011 was 400 bcm according to Eurogas.37 Or to express it another way, if one assumes that natural gas could be supplied to the European Union (EU) for 25 years - a typical period for gas supplies - the estimated gas in Block 12 is only enough to supply $2 \%$ of the EU27's needs each year. This rises to $5 \%$ if one adds Israeli proven reserves." For detail, see Ayla Gürel, Fiona Mullen and Harry Tzimitras, The Cyprus Hydrocarbons Issue: Context, Positions and Future Scenarios (PCC REPORT 1/2013 of PRIO Cyprus Center), (Oslo, Norway: Peace Research Institute Oslo (PRIO), 2013), 8.

2 Sertaç Hami Başeren, Doğu Akdeniz Deniz Yetki Alanlarında Hukuk ve Siyaset [Law and Politics at the Eastern Mediterranean Maritime Jurisdiction Areas] (Ankara: A.Ü. SBF Yayını, 2013), 253.

${ }^{3}$ For detailed information, see Hüseyin Pazarc1, Uluslararası Hukuk [International Law] (Ankara: Turhan Kitapevi, 2009), 233-299.

4 This Latin phrase means "from the beginning". Meriam Webster, accessed December 22, 2014, http://www.merriam-webster.com/dictionary/ipso\%20facto.

5 This Latin phrase means "by that very fact or act". Meriam Webster, accessed December 22, 2014, http://www.merriam-webster.com/dictionary/ab\%20initio.

61982 UNCLOS, accessed December 23, 2014, http://www.un.org/depts/los/convention_agreements/texts/ unclos/unclos_e.pdf

${ }^{7} 1$ nautical mile is 1.852 meters.

${ }^{8}$ UNCLOS, 1982, Articles 56(3), 57 and Part VI on the Continental Shelf. For detailed information about sea areas in international rights, see the map in Annex-1.

${ }^{9}$ Kağan İlter, "The Eastern Mediterranean: Energy, Maritime Security and Strategic Alliances" (MA diss., Naval Post Graduate School, 2012), 62.

${ }^{10}$ The EEZ treaty between Greek Cypriots and Egypt was signed in February 2003.

${ }^{11}$ The EEZ treaty between Greek Cypriots and Lebanon was signed in January 2007.

12 The EEZ treaty between Greek Cypriots and Israel was signed in December 2010.

${ }^{13}$ For detailed information about limitations of EEZ among littoral states, see the map in Annex-2.

${ }^{14}$ According to UNCLOS article 74(1), the EEZ delimitation between states with adjacent or opposite coasts, is regulated following an agreement, aiming to achieve a fair solution (equitable result). In cases where reaching an agreement is not possible, according to UNCLOS Part XV, the interested parties must resort to conciliation for the settlement of the difference (article 74(2)).

${ }^{15}$ Çağatay Erciyes, "Maritime Delimination and Off-Shore Activities in the Eastern Mediterranean: Legal and Political Perspectives, Recent Developments.", Maritime Delimination and Off-Shore Activities, accessed December 03, 2014, http://www.mfa.gov.tr/site_media/html/maritime_delimitation.pdf.

16 Turkish Permanent Representation Note to UN SecGen dated 2 March 2004, 2004/Turkuno DT/4739.

17 Noble Energy, "Recent Discoveries," Noble Energy Inc., accessed December 17, 2014, http://www. nobleenergyinc.com/Exploration/Recent-Discoveries-130.html

18 İlter, "The Eastern Mediterranean: Energy...", 63.

${ }^{19}$ Soyalp Tamçelik, "Kıbrıs'ta İngiliz Üslerinin Stratejik Önemi," [Strategic Importance of the British Bases on Cyprus] Uluslararası Insan Bilimleri Dergisi [International Human Sciences Periodical] 8(1) (2011): 1513 (1510-1539).

${ }^{20}$ George Kirk, "The British Regime in Cyprus," in The Middle East 1945-1950 (Survey of International Affairs), (London: Oxford University Press, 1954), 159-187.

${ }^{21}$ For detailed information about the all known British bases and military facilities, see Mustafa Haşim Altan, Kıbrls'ta Türk Malları II: Gaspedilen ve Yitirilen Türk Tapu ve Arazi Hakları, [Turkish Estates in Cyprus II] (4 Volumes) (İstanbul: Kastaş Yayınevi, 2001): 486-528.

${ }^{22}$ Ahmet C. Gazioğlu, "Kıbrıs ve İngiliz Üsleri," [Cyprus and the British Bases] Kıbrıs Türk Stratejik Araştırmalar Dergisi 3 (2010): 4 (4-5).

${ }^{23}$ Ercüment Tutar, "Egemen İngiliz Üsleri ve Küresel Bağlantıları," [Sovereign British Bases and Global Connections] Klbris Türk Stratejik Araştırmalar Dergisi, (2010): 49-58. 
24 Ata Atun, "Kıbrıs'taki İngiliz Üsleri," 13 May 2011, accessed December 26, 2014, http://www.ataatun.org/kibris\%E2\%80\%99taki-ingiliz-usleri.html.

${ }^{25}$ For detailed information about these two states, see https://www.cia.gov/library/publications/the-worldfactbook/wfbExt/region_eur.html, accessed December 26, 2014.

${ }^{26}$ Ata Atun, "Kıbrıs'taki İngiliz Üsleri,".

${ }^{27}$ US Secretary of Defence, "International Boundry Study - Series A: Limits in the Seas / Territorial Sea Boundry / Cyprus-Sovereign Base Area (U.K.) / No. 49," Issued by the Geographer, 10 November 1972, 2 (14).

28 "Treaty Concerning The Establishment of The Republic of Cyprus", Republic of Turkey Ministry of Foreign Affairs, accessed December 27, 2014, http://www.mfa.gov.tr/treaty-concerning-the-establishment-of-therepublic-of-cyprus.en.mfa.

${ }^{29}$ Çavlan Süerdem, "Kıbrıs'taki İngiliz Egemen Üsleri ve Düşündürdükleri," [Sovereign British Bases on Cyprus and Their Effects in Consideration] Kıbrıs Türk Stratejik Araştırmalar Dergisi, 3 (2010): 8 (8-9).

${ }^{30}$ Ibid.

${ }^{31}$ For detailed information about this sensitive issue, see the map in Annex-3.

${ }^{32}$ The legal status of these sea areas seems debatable. According to Scovazzi (2012), they “...could in principle be either British territorial sea or high seas or even, where they are located beyond the 12-mile limit, the exclusive economic zone of Cyprus." Scovazzi also notes that "...[d] espite the Treaty [of Establishment], the straight baseline system established by Cyprus in 1993 encloses the SBAs, as if they had no coastal waters of their own." For detail, see Tullio Scovazzi, "Maritime Boundaries in the Eastern Mediterranean Sea. Policy Brief," GMF Mediterranean Policy Program, Eastern Mediterranean Energy Project, 2012, accessed December 28, 2014, http://www.gmfus.org/archives/maritime-boundaries-in-the-eastern-mediterranean-sea/.

33 Jonathan I. Charney and Lewis M. Alexander, International Maritime Boundaries, Vol II (Dordrecht, The Netherlands: Martinus Nijhoff Publishers, 1991), 1559-1560.

34 "The British too fianced to the Black Gold in the Aegean," Ta Nea, February 17, 2007, 3.

35 "The UK Claims Hydrocarbons of Cyprus," To Vima, February 11, 2007, 1.

36 "UK Surveys Around Cyprus," Fileleftheros, February 27, 2005, 1.

37 The UK has expressed on several occasions that were any hydrocarbon reserves to be found within the Sovereign Bases Areas or their territorial waters or continental shelf then the UK would not seek to exploit them herself, in line with its declaration at Appendix $\mathrm{O}$ to the Treaty establishing the Republic of Cyprus. (Appendix O concerns the Declaration by Her Majesty's Government regarding the administration of the Sovereign Base Areas.) For detail, see Gürel, Mullen and Tzimitras, The Cyprus Hydrocarbons Issue, 13.

38 Sertaç Hami Başeren, "Doğu Akdeniz Deniz Yetki Alanları Uyuşmazlığı," [Disputes over Eastern Mediterranean Maritime Jurisdiction Areas] Stratejik Araştırma ve Etüt Merkezi (SAREM), 8(14) (2010): 154155 (129-184).

39 "Doğu Akdeniz Kıta Sahanlığı ve Türkiye'nin Stratejisi," [Continental Shelf in the Eastern Mediterranean and Related Turkish Strategy] (Panel) (Ankara: Başkent University Center for Strategic Researches, 2007): 32, 34 (1-64).

${ }^{40}$ Başeren, "Doğu Akdeniz Deniz Yetki Alanları Uyuşmazlığı," 132.

${ }^{41}$ Süerdem, "Kıbrıs'taki İngiliz Egemen Üsleri ve Düşündürdükleri," 9.

${ }^{42}$ Retrieved on 24 December 2014 from http://en.wikipedia.org/wiki/Exclusive_economic_zone 